\title{
Christian Bobin's Life Pursuit in Death Dominated Universe
}

\author{
Saeid Rahimipour \\ Assistant professor, Farhangian University \\ Pazoheshblv, Ilam, Iran
}

\begin{abstract}
Life has been a gift of God granted upon man. The way man has tried to lead his life, understand its real meaning, immortalize it, and avoid the unpredictable death hovering over existence has become the great obsession of man. Whenever man finds an opportunity away from the obsessions of everyday life, he tries to fathom this unattainable reality. To live with the Sword of Damocles threat of death has blurred the joy of life and assigned a bitter absurdity. Intellectuals, more than ordinary people, realize this reality that the sheer negligence of death may be the source of horror and anguish. But in reality, as the main purpose of this paper and as the major view point of Bobbin achieving after many years of working, thinking, and writing reveals this fact that the awareness of the ever unpredictable nature of death brings the real meaning to the life and being, an idea that flourishes every second of our existence and being; otherwise, we lose our life by the threat of death and negligence of the worth of our granted gift, our life.
\end{abstract}

Keywords: Bobin, Death, Pursuit, Life, Universe

\section{INTRODUCTION}

Christian Bobin was born in 1951 in Le Creusot, a Burgundian town with a long industrial and mining history where he lived his whole life. His name resembles that of John Bunyan's Pilgrim progress.

He published short texts regularly from 1984 onwards and gradually attracted reviewers and public attention. Although two of his books have appeared in America, he has remained somehow unknown in other academic settings. This may be because he has not been well-off, or maybe he has ignored fame as all other things he has been offered in his life. This is what has made his idiosyncrasy of his view of life and existence. This is his tact in finding meaning for life as Matarasso the translator of his work has asserted that dates, events, any sense of a willed, let alone planned, progression through the years are as absent as Bobin has been able to make them, partly because he sets no value by these he could manage. The book selected to write this article about is the Eighth day of the Week which is indeed a collection of works published from 1985 to 2012 and have been translated by Pauline Matarasso. As a translator of the English version of his work from that of Matarasso, I detected some strange but really novel themes like how can we feel and live our life in the deadly world, the alluring time killing values depriving us of our life, the ever presence of hovering death over our existence, the unpredictability of our tomorrow and our next breath maintenance. Bobin himself adapted from Matarasso's introduction indicates that 'I don't remember ever wanting this or that kind of life. From childhoodon I have put my every effort into refusing whatever was proposed to me, pushed by something I couldn't put a name to and still can't'. The way Bobin has managed them all, the way he has always experienced death and fighting against it to live is really appeasing. The research shares these atmospheres and the ways Bobin has tried to entice us into encompassing this reality from the view point of many incidents.

\section{DisCUSSION}

What is the eighth day of the week? Was it the day upon which God rested after creation of the world? Isn't it alluring that we want to immortalize our being by adding days to the week that do not exist in time and place? Isn't it a day in which we are left in vacuum of our being to think about life, death, and universe?

Many a people have given it a try for finding a way of immortalizing their life and existence. So many intellectuals have tried to make our life tangible and understandable. Chemists through their chemical studies, philosophers through their sophistication and philosophizing, literary intellectuals through 
their maneuver over words, themes, literary techniques, and via any literary activity. Whenever they want to get to a higher level of understanding of life and the ever increasing and its neighboring death, he takes refuge in whatever way possible to reveal his innermost feelings of death hovering over his life and being, the unwanted coming into the world, and the imminent bitter succumb to death and mortality; the short pace of life, and the many threats of different types on the way of life from diseases, to war; from heart attach to an ominous unknown power system decision over our being. The sheer nature of the question of determinism to the hotly debated dilemma of choice over our decisions and actions may open up new challenges. A look at the life of many an intellectuals of the same obsessions like Peter Porter makes it demanding and alluring. Peter Porter is an Australian who went to England in the early 1950's and whose first poems were published in the 1960s. His work is often sharply satirical, full of realistic details of material objects and the appearance of things and people, but also has a deeper and more universal quality since he is always conscious of the presence of death, a force that man cannot fight against:

And if we shout

At the gods, they send us the god of death

Who is immortal and who cannot read. (Thornley \& Roberts, 1988:195).Bonin may have been afflicted by this thematic obsession and has tried to reveal through short stories collected in a volume following and serving an interestingly coherent theme, characterization, and life survey in the Eighth Day of the Week. His techniques, mode of thinking, and concepts deployed in the book contribute to meaning assignment to, and pursuit of life.

To him life is encompassed by the Camus' absurdity afflicting modern man. Bobin embraces this hollow condition: 'I love these hours as one can love an awkward child....yes, I love this barren inglorious time'. He has "published novels, stories, essays, biographical works, none of which exactly fits the genre to which it apparently belongs" (Keegen, 2). On this line, he adds "his themes are simple: nature, childhood, parents, momentary encounters, aloneness, the eventless of the everyday as it strikes a receptive apparatus of exceptional resilience and inwardness-and, yes, idiosyncrasy" (2). Throughout all the stories runs a senseless, unstable, and ever-on-the-alert view of life for facing death. Such ideas are projected in the selection of the atmosphere of his short stories and the characters whose existence in at the mercy of moments of uncertainty. To deal with the nature of being, as keegen asserts Bobin's vagrant ethos-his hedgerow indigence-defines both him and his belief."'(2)

Paul keegen reveals that the kind of setting he has chosen to put his themes in on the way of flourishing is ideas has attributed to his tact. One section of the Eighth Day of the Week is in a care home for Elderly Alzheimer's patients including his own father. A far off village in which life has been wiped out. God has already evacuated there. Another setting is the retirement home of his mother. For sure, he willingly due to his loneliness and the absence of any acquaintance except the memory of a woman he already loved but is dead now and the introduction of a little girl in far parts of the short stories cannot be detected, will end up here too. This imminent presence and tangible condition of his own life in the future now envisaged in his mother and father has mentally and existentially violated and has enticed him into finding a way of experiencing life and enjoying rather than waiting for the bitter death sticking many old man and women he witnesses every day. This goes to a climax when he feels the smell of the dead in the elevator, in the discolored mirror of the rooms, and the misery of the blossoms of the trees to flirt with the young not the waiting-for-death elderly he wholeheartedly perceives.

His characters are all old moms and dads. The old people working hard and living alone and in his own fantasy. His imaginary characters are little girls out of reach and out of real life and being. Women were the second in priority in his works. He wrote an elegy in 1999 in commemoration of his beloved wife. Even the majority of the Eighth Day of the Week has been written under her eye and her presence. Her mother, the old woman, his deceased beloved, Helene, The tight Walker's beloved. The vignette in 'The killer White as snow'. Jonah in Get Moving, Jonah, I'm waiting who is left alone in the whale belly.

Bobin is afflicted with the concepts of death. Bobin: The man in the room next to my mother's died two weeks after his arrival in the home. Each time for me to see something of his elegance, his weariness and his soul, worn as thin as a used bar of soap that keeps slipping through the fingers. His room has disappeared from the door of his room, and the glean of the newly white card sears like a 
mystery. Such assertions all are poured out because of the inner mind view of death in his work." Death agonies, long-drawn, are presented as entertainments [like today]. The chamber of suffering is open like the others and the audience is held there" (EDW, 2). The news of so many deaths, injuries, and life losses by war, diseases, or accidents all has on the one hand made the routine report of the officials and on the other hand, the imminent threat on the way of others. This is the idiosyncrasy of modern world.

As for hope for life, Mattarasso asserts that his life is "like a boisterous child". At times of inner derelecition he is 'sequestered like a child sent supper less to bed". But happily -for some fasts are necessary -no one comes to revoke the punishment, and when the child emerges in the morning, he washes the darkness from his face and in rainwater and finds life waiting for him out of doors". (V) With this regard, "Camus believed that, despite the limitations in perspective and the absurdity of life, humans can make decisions that lead to less suffering. This is not the eradication of evil...it is instead the work of human to reduced suffering when they can, to act with the acceptance that all cannot be healed, resolved, or explained on this earth" (White, 557). This is because as Genioveseasserts "hope becomes useless because it is concerned with the future rather than the present, and the future is nonexistent. In fact, it is only though Absurdism that one may fulfill her/his greatest potential for optimism, passion, and insight"(3).

Philosophical thinking is prevalent throughout his book. He has directly or indirectly been afflicted by the same mode of thinking and behavior. To one he is most accompanied is Kierkegaard who is generally regarded as the founder of modern Existentialism. Although rationalism has been in common practice in the past and its proponents even exist today, yet, it was Kierkegaard who established the concepts that influenced later intellectual among whom we can refer to Bobin who can best be understood at the shadow of the philosophical findings. Like Camus (1980) he confirms that the only comprehension a man has is one of a difference. In this way, man retracts himself because he feels threatened by the disconnection of the world, provoking conflicts. Bobin spends most of the days alone, with his father at the last resort in which he witnesses the death of many old men and women. He experiences life with the determined and hovering death as the ultimate destiny of man; therefore, the idea of the world and the imminent journey obsesses him and tries to assign meaning to the seconds of his life. He reacted against the absolute idealism of traditional philosophers Kant and Hegel who considered philosophy as a science. In his pursuit of meaning of life and he comes to the idea that as Kierkegaard has asserted knowledge is an unattainable ideal. On this, Bobin agrees with him and finds fault with these philosophies for their abstract hypotheses and their pretensions to answer existential obsessions without even posing the primary questions about the meaning of life and identity. Kierkegaard paves the way for him in this quest that seeking' absolute knowledge', is only a limited human being and cannot go beyond it. Like Hegel in following rational understanding of humanity and the history of humanity, he fails to capture a good vision of life and its accompanying death. Just like Kierkegaard, on the other contrary, asserted the ambiguity and absurdity of the human situation, and believed that the individual's response to this situation must be to live a totally committed life, and this commitment could only be understood by the individual who has made it. He gradually comes up with this reality that "the individual must always be prepared to reject the norms of society for the sake of the higher authority of a personally valid way of life. Kierkegaard ultimately advocated a "leap of faith" into a Christian way of life which was the only commitment that could save the individual from despair (593, 2010, Yegane)".

Regarding his self and identity, he seems to be a proponent of Dickenson to whom he devoted a brief imaginary biography: 'I'm no body! Who are you? Are you nobody, too? How dreary to be somebody!' Paul Keegen (IV). To Keegen, Bobin is interested in the luxury of introspection, we receive what is inside us from outside. He compares Bobin with Kafka with, namely, the kafka who could write indicating the crisis of identity and self in his Trial. Paul keegen adds "what I most admire in Bobin, almost, is his unexpected ferocity. His distrust of public faces in private places. Genovese in two different sections asserts that "ambiguity of time, place, and identity lend themselves seamlessly to a meaningless plot where the implications of events are more important than the events themselves" (10). Finding meaning in this meaningless world calls for great tact to lead your time happily because " no one is capable of predicting precisely how any event will unfold, or what repercussions of an event will be . Time, Space, identity, and even truth, then, do become arbitrary and thus the traditional methods of exchanging such ideas become arbitrary" (11). This makes the Burdon of meaning assignment to life demanding for him in such atmosphere. 
He does not get disappointed in his search for life. Pual Keegen, hence forth, indicates that the world will freely offer itself to you to be unmasked, it has no choice, and it will roll in ecstasy at your feet. On the way of finding the meaning of life he says: 'we need no guard, not only against the world, but against our preoccupation with ourselves, another door by which the world might creep back in like a prowler into a sleeping house.' Hence, we must get away from the crowd out there, but also from the crowd inside ourselves. We are the obstacle that stands between us and an unobstructed view (Keegen, Introduction).

Bobin is afflicted with the idea of Camus (1980) that the feeling of absurdity is because of the consciousness man acquires of his condition as human being. The kind of interpretation and mode of living this man follows brings the desired meaning to his life and his being. However, this may not goes on as wished due to the fact that "man lives according to the rules and traditions of the place he lives in" (Goncalves, 134) if he wants to violate the rules and live his own interpreted life he will end up as the a mere special outcast. This may be a big factor behind the inaccessibility of the real meaning and experience of life as perceived. Bobin well has understood this reality and sets everything that drives him to the corner from the fame to financial gain. He chooses his own amount from everything around him. He cannot fathom life, "where we are-in the eternal moment- there are no words, since everything is present. Where we are not-in the passing hour- only words are left, balled together like birds' down forgotten by the wind in rutted tracks '(P.17). The types of characters in the Eighth Day of the Week all share this outlook of the world and life. The Tight Walder, Mozart, and all other segments of his novel have such a trend in characterization.

Man has to find a way for his best leading of his life because in this absurd world as Genevose has indicated "God is no longer available to provide comfort. Human must interpret their sensory experiences, make decisions, live with both the consequences and limiting nature of those decisions, and accept the impossibility of understanding non-human ways of being (3).

As his final solution of uncovering the reality of being and handling death, he turns to solitude as a way of seeing rather than a pious removing. And what it sees is far from bad news. He has time to pay attention to what he hears rather that what he says. To him "this is a tale with nothing to say" (p.4). " On goes the tale, the tale of this morning with nothing to tell, It doesn't end until-in the quiet withdrawal of evening- I wish to write about it: then the words grow faint and what they name is seen as from a great distance, like a fire catching in the face of sleep" (EDW,IV). He tries to find life in silence. An old woman admits that she is "so lonely that she hears "the noise of the light bulb" when eating in her kitchen. On the way of getting closer to the real meaning of ourselves and lives, Keegan reveals "his writing persuades us that here we have one manifold definition of being alive-as a position without defenses. "all we can do is welcome it ...It borrows our body for a while and will outlive it. 'Again, we think of the ancient Greeks- and I think again of Winicott, the practitioner of a modern and wholly secular practice of the self-which may seem a farfetched connection, but who originally was comparably hard-won and patient, who wrote that ' it is a constant struggle to get to the starting point, and to stay there.' It can be concluded that "people have to find their own meanings and apply them to their values; judging and learning, to make life a place worth living" (Goncalves: 2006, 140).

\section{Conclusion}

Bobin in his work like many intellectuals tries to find the solution of the existential obsession stargeting human being the prominent of which is the death bordering life dilemma. He has crystalized such things in the Eighth Day of the Week to pave the way for the better understanding of the nature of death and the reality of existence. His selection of setting, his philosophizing, themes, characterization, and delicate techniques reveal the fact that to fathom the reality of life is to surpass the boundaries of death, its ever presence, and its dominating power, as well as the abandonment of all characteristics which limit life to get to the reality of being in the death-stricken life in the universe. He himself finely reveals his understanding of life when he answers a child who asked him "'what is beauty?'- And it could only be a child, for that is the only age that hankers after lightning and frets about what matters-I should answer: beauty is in in all things that move away after once brushing our skin. Beauty is in the radical instability- a loss of balance and of voice- that the passing touch of a white wing provokes in us. Beauty is the sum of those things that pass through us, unaware of us, and suddenly intensifying the lightness of being" (EDW, 21). 


\section{REFERENCES}

[1] Genevoses, K. Maria. (2010). Meaningful Meaninglessness: Alber Camus' Presentation of Absurdism as a Founation for Goodness (Pell Scholars and Senior Theses. Paper 60.http// digitalcommons. salve.edu

[2] Goncalves, Tatiane (2006). A Reading of the Theme of Exiles in the Light of the Myth of Sisyphus. Fragmentos, numero 30, p.129/141Jun.

[3] White, Holly (2006). "Practice Camus". Cross Currents 55.4, 554-563. Academic Search Complete. Ebsco. Web 19 Nov. 2009.

[4] Yegane, Farah (2006). Literary Schools. Iran: Rahnama Publication. 